\title{
Temporal and Directional Patterns of Nymphal Halyomorpha halys (Hemiptera: Pentatomidae) Movement on the Trunk of Selected Wild and Fruit Tree Hosts in the Mid-Atlantic Region
}

\author{
Angelita L. Acebes-Doria, ${ }^{1,2}$ Tracy C. Leskey, ${ }^{3}$ and J. Christopher Bergh ${ }^{1}$ \\ ${ }^{1}$ Alson H. Smith Jr. Agricultural Research and Extension Center, Virginia Tech, Winchester, VA 22602 (aacebes@vt.edu; \\ cbergh@vt.edu), ${ }^{2}$ Corresponding author, e-mail: aacebes@vt.edu, and ${ }^{3}$ USDA-ARS, Appalachian Fruit Research Station, 2217 \\ Wiltshire Rd., Kearneysville, WV 25430 (tracy.leskey@ars.usda.gov) \\ Subject Editor: Joe Louis
}

Received 5 September 2016; Editorial decision 19 November 2016

\begin{abstract}
Halyomorpha halys (Stål) (Hemiptera: Pentatomidae) is an invasive and polyphagous herbivore that has been problematic in Mid-Atlantic fruit orchards, many of which are adjacent to woodlands containing its wild hosts. Our tree census in woodlands bordering 15 Mid-Atlantic apple orchards revealed 47 species of deciduous trees and shrubs, $76.6 \%$ of which were recorded hosts of $H$. halys. Tree of heaven was most common and abundant overall. Halyomorpha halys nymphs have a substantial walking dispersal capacity, and their fitness is enhanced by feeding on multiple hosts. Directional and temporal patterns of nymphal $H$. halys movement on selected wild hosts and apple and peach trees at the orchard-woodland interface were monitored in 2014 and 2015 using passive traps to capture nymphs walking up and down tree trunks. Weekly captures from mid-May to late September or midOctober were compared among hosts across both seasons. Despite higher total nymphal captures in 2014 than 2015, the seasonal trends for both years were similar and indicated bivoltine $H$. halys populations. In both years, more nymphs were intercepted while walking up than down and captures of upward- and downward-walking nymphs varied significantly among the hosts. All instars were captured, but captures of second instars predominated. Captures reflected seasonal changes in instar distribution and consisted predominantly of younger and older nymphs, early and later in the season, respectively. Results are discussed in relation to host and seasonal effects on the movement of nymphs at the orchard-woodland interface, and the implications for $H$. halys management.
\end{abstract}

Key words: brown marmorated stink bug, apple, peach, tree of heaven, tree survey

Halyomorpha halys (Stål) (Hemiptera: Pentatomidae) is an invasive, herbivorous stink bug from Asia that was detected in the United States in the mid-1990s (Hoebeke and Carter 2003) and is reported to utilize $>100$ plant species, including many agricultural and horticultural crops (Rice et al. 2014). In 2010, its populations reached critical levels in the Mid-Atlantic region, resulting in considerable economic losses to many crops, and particularly in tree fruit orchards (Leskey et al. 2012a). In response to the threat posed by $H$. halys, initial research efforts focused on identifying effective insecticides for its management. Many of the most effective products (Kuhar et al. 2012, Leskey et al. 2012b, Lee et al. 2013a) are broadly toxic to arthropods and their increased use by growers in the postbloom period led to increased outbreaks of secondary pests (Leskey et al. 2012c). To assist a return to more sustainable orchard pest management practices, current research priorities include the development of management strategies for $H$. halys that require a broader and deeper understanding of its behavior and ecology.
In Mid-Atlantic tree fruit orchards, $H$. halys is considered to be primarily a perimeter-driven threat. Blaauw et al. (2016) collected more $H$. halys adults along orchard borders, and Bergh and Leskey (unpublished data) recorded highest captures of $H$. halys nymphs and adults in pheromone traps at the edges of adjacent woodlands and orchards than in those deployed in the woods or orchard interior. Moreover, higher levels of fruit injury from $H$. halys have been recorded from orchard border rows next to woods than from the orchard interior (Leskey et al. 2012c, Joseph et al. 2014). Aside from the considerable dispersal capacity of $H$. halys nymphs and adults (Lee et al. 2014, Wiman et al. 2014, Lee and Leskey 2015), its invasion of fruit orchards over an extended period during the growing season is likely exacerbated by the availability of wild hosts in these wooded areas. A survey of $H$. halys in the eastern United States showed that it reproduces and feeds on many tree species (Bakken et al. 2015). However, the species composition and relative abundance of these hosts in unmanaged woodlands adjacent to Mid- 


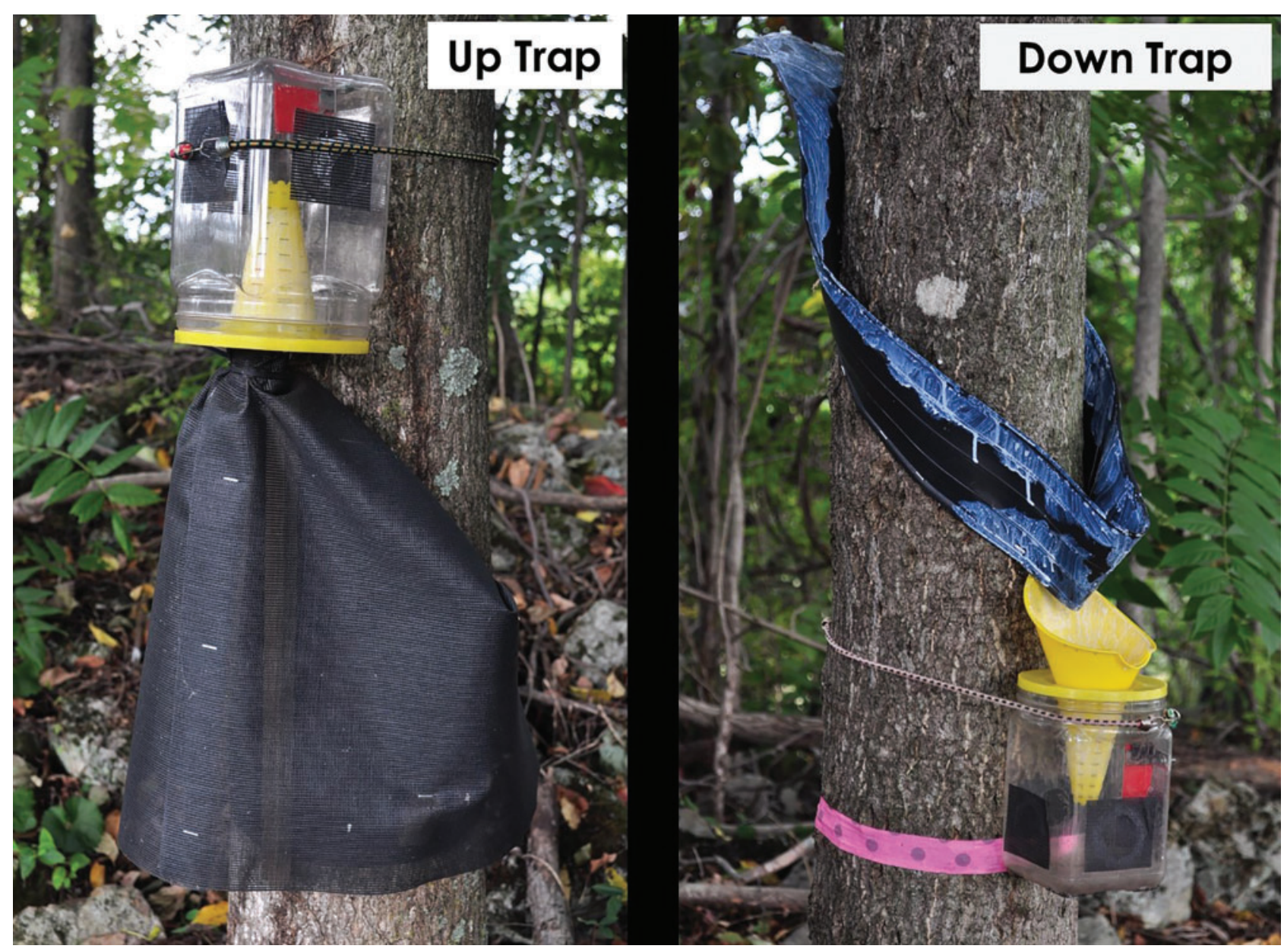

Fig 1. Up and down traps used, respectively, to capture H. halys nymphs walking up and down trunks of selected wild and fruit tree hosts at the orchardwoodland interface at three apple orchard and two peach orchard sites in Virginia and West Virginia in 2014 and 2015.

Atlantic fruit orchards has not been characterized; documenting this may enable deeper insights into the localized threat from $H$. halys and the risk of its invasion of orchards.

Several native stink bug species are considered pests of orchard crops, although only the adults are known to feed on fruit. Conversely, both nymphs and adults of $H$. halys feed on and injure apples, peaches, and other tree fruits (Acebes-Doria et al. 2016a), highlighting the potential importance of nymphal movement among hosts at the orchard-woodland interface. Halyomorpha halys nymphal survivorship and developmental rate are enhanced when they feed on multiple plant hosts (Funayama 2006, Acebes-Doria et al. 2016b), which may at least partially explain their highly dispersive behavior. Lee et al. (2014) demonstrated that nymphs walked $20 \mathrm{~m}$ within $4-5 \mathrm{~h}$ on a grassy field in response to pheromone lures. In the laboratory, nymphs walked up to $41 \mathrm{~m}$ in $1 \mathrm{~h}$ and up to $8 \mathrm{~m}$ in 15 min on smooth horizontal and vertical surfaces, respectively (Lee et al. 2014). Nymphs also have been observed walking up and down tree trunks, leading Acebes-Doria et al. (2016c) to develop and compare traps to monitor this upward and downward movement, based on designs used by other researchers to monitor pecan weevil (Coleoptera: Curculionidae) on pecan trees (Mulder et al. 1999) and to survey arthropod communities in a New Zealand forest (Moeed and Meads 1983). Different trap designs proved most effective for capturing $H$. halys nymphs walking up or down (Acebes-Doria et al. 2016c) and enabled research on the directional and temporal movement patterns of $H$. halys nymphs on cultivated and wild trees at the orchard-woodland interface. Such ecological studies can enhance our understanding of nymphal dispersal trends during the season and may help to predict the timing of orchard invasion and periods of increased pest pressure, both vital to developing temporally and spatially precise pest management programs. Thus, the objectives of this study were to quantify the relative abundance and species composition of potential tree hosts of $H$. halys in unmanaged wooded areas adjacent to commercial fruit orchards in Virginia and West Virginia and to monitor seasonal patterns of nymphal H. halys movement onto and off of trees at the orchard-woodland interface, using passive traps installed on tree trunks.

\section{Materials and Methods}

\section{Tree Census}

One experimental and 14 commercial apple orchards in Virginia and West Virginia were selected, all of which had an unmanaged woodland at $\leq 25 \mathrm{~m}$ from at least one border (Supp. Table 1 [online only]). Sampling areas $\left(10 \mathrm{~m}^{2}\right)$ at the woods edge $(n=3$ per site) and in the woods interior $(n=3$ per site) were surveyed. The interior areas were 40-60 $\mathrm{m}$ inside the woodlot from the edge and the edge and interior sampling areas were separated by 10-30 m. All trees and shrubs that were $\geq 1 \mathrm{~m}$ tall within each sampling area were identified to species and counted. Species identification used dendrology 
Table 1. Orchard sites at which H. halys nymphs were trapped in 2014 and 2015

\begin{tabular}{|c|c|c|c|}
\hline Orchard location & Fruit tree & Main wild host & Other wild hosts \\
\hline Winchester, VA & $\operatorname{Peach}^{a}(5,5)$ & Tree of heaven $(5,5)$ & Black cherry $(3,3)$, Black locust $(1,1)$, Hackberry $(1,1)$ \\
\hline Kearneysville, WV & $\operatorname{Peach}^{b}(5,5)$ & Tree of heaven $(5,5)$ & $\begin{array}{l}\text { Black cherry }(1,1) \text {, Boxelder }(1,1), \text { Hackberry }(1,1), \\
\text { Mulberry }(1,1) \text {, Sassafras }(1,1)\end{array}$ \\
\hline Winchester, VA & Apple $^{c}(5,5)$ & Tree of heaven $(5,5)$ & Black cherry $(2,2)$, Black locust $(2,2)$, Sassafras $(1,1)$ \\
\hline Winchester, VA & Apple $^{d}(5,5)$ & Tree of heaven $(5,5)$ & Green ash $(1,1)$, Sweet cherry $(1,1)$, Black Walnut $(1,1)$, Hackberry $(2,2)$ \\
\hline Winchester, VA & Apple $^{e}(5,5)$ & Tree of heaven $(5,5)$ & Black cherry $(1,1)$, Black locust $(1,1)$, Hackberry $(1,1)$, Sassafras $(2,2)$ \\
\hline
\end{tabular}

Numbers in parentheses indicate the number of trees with up and down traps (up, down).

a 13 -yr-old 'Redhaven'; spacing: 3.7 by $7.6 \mathrm{~m}$.

${ }^{b} 18$-yr-old 'Loring'; spacing: 3.1 by $3.4 \mathrm{~m}$.

${ }^{c} 18$-yr-old 'York' on M.7 rootstock; spacing: 3.7 by $6.1 \mathrm{~m}$.

${ }^{d} 17-19$-yr-old 'Fuji', 'Ginger Gold', and 'Gala' on M.9 rootstock; spacing: 2.1 by $4.9 \mathrm{~m}$.

e 13-15-yr-old 'Ida Red', 'York', and 'Ginger Gold' on M.111, M.26, and M.7, respectively; spacing: 5.5 by 7.9 m.

Diameter at breast height $(\mathrm{DBH})$ of wild hosts: Black cherry-14.15 $\pm 0.99 \mathrm{~cm}$; Black locust $-14.25 \pm 1.14 \mathrm{~cm}$; Green ash-7.69 $\pm 0.11 \mathrm{~cm}$; Hackberry$11.91 \pm 0.71 \mathrm{~cm}$; Mulberry-8.03 $\pm 0.26 \mathrm{~cm}$; Sassafras $-14.21 \pm 1.09 \mathrm{~cm}$; Sweet cherry $-15.51 \pm 1.50 \mathrm{~cm}$; Tree of heaven $-18.24 \pm 0.68 \mathrm{~cm}$.

factsheets from http://dendro.cnre.vt.edu/DENDROLOGY/factsheets. cfm (accessed 20 October 2016). The abundance of each tree species relative to the total number of trees identified was calculated for the interior and exterior sections of the woodlands.

\section{Nymph Traps}

The passive traps used were described and compared by AcebesDoria et al. (2016c). The "up" trap was designed to intercept upward-walking nymphs while the "down" trap was intended to capture nymphs walking down tree trunks (Fig. 1). Briefly, the up trap was a modified version of the "Circle" trap originally used to monitor pecan weevil (Mulder et al. 1999), constructed of a mesh funnel leading to a piece of PVC pipe that, in turn, led to the inside of a plastic collection jar. The down trap was loosely based on the design used by Moeed and Meads (1983) to survey the invertebrate communities on trees in a New Zealand forest. The guiding portion of the down traps was a black plastic collar wrapped diagonally around the trunk, with one edge stapled to the trunk. An opening in the stapled edge led to a plastic funnel that, in turn, led into a plastic collection jar. To allow drainage of water, the down traps had small, screen-covered holes in the bottom of the collection jar. Selected surfaces on or in both traps were coated with a fluoropolymer resin, PTFE-30 or fluon (BioQuip Products Inc., Rancho Dominguez, CA), a slippery material that served to prevent $H$. halys escape from the collection container and from walking over the funneling or guiding feature of the traps (Fig. 1). The size of the mesh funnels or collars was tailored to fit the circumference of the trunk of individual trees selected for trapping. The average trunk diameter where traps were installed was $38.01 \pm 0.90 \mathrm{~cm}$ and ranged from 19.24 to $92.17 \mathrm{~cm}$ across the different host trees used. A strip of Vaportape II (Hercon Environmental, Emigsville, PA) containing dimethyl-2,2dichlorovinyl phosphate was suspended inside the collection jar of each trap and served to retain the $H$. halys captured. These were replaced at 2-wk intervals, based on established protocols (Joseph et al. 2013, Weber et al. 2014).

\section{Field Sites and Trap Deployment}

Three commercial apple orchards near Winchester, VA, were selected, based on the fact that they contained fruit for processing and therefore were not treated with insecticides targeting $H$. halys and that they had at least one border adjacent to an unmanaged woodland (Supp. Table 2 [online only]). The two experimental peach orchards used were located at Virginia Tech's Alson H. Smith AREC (AHS AREC) in Winchester, VA, and the USDA Appalachian Fruit Research Station (AFRS) in Kearneysville, WV (Supp. Table 2 [online only]). These orchards also were next to wooded areas and were not treated with insecticides for $H$. halys. All fruit in the experimental peach trees were removed on 7 August 2014 and 5 August 2015 to simulate peach harvest in commercial orchards. The apples cultivars used were harvested in mid-August (Ginger Gold), late August/early September (Gala), or mid- to late October (Ida Red, Fuji, and York).

At each site, traps were deployed on fruit trees in the orchard border row adjacent to the woodlot and on wild trees at the edge of the woodlot. The mean $( \pm \mathrm{SE})$ distance between the orchard and woodlot edges was $23.30 \pm 3.33 \mathrm{~m}$ and ranged from 6.8 to $80.6 \mathrm{~m}$. At each site, five pairs of apple or peach trees along the orchard border were selected for trapping. Trees within each pair were separated by $9.63 \pm 0.97 \mathrm{~m}$, and the average distance between pairs of trees was $39.95 \pm 6.82 \mathrm{~m}$. One up trap and one down trap was deployed on each pair of trees. Along the woods edge at each site, five pairs of female tree of heaven were selected. At the location of each pair of tree of heaven, a pair of another known wild tree host of $H$. halys was also selected, the species of which varied among locations at each site, based on the composition of the forest at each point along the woods edge (Table 1). These tree species were chosen based on the results of the tree census, on the list of $H$. halys hosts reported by Bakken et al. (2015), and on StopBMSB.org (accessed 20 October 2016). Wild trees within each pair were separated by $3.25 \pm 0.83 \mathrm{~m}$, and the distance between pairs of trees was $24.04 \pm 4.53 \mathrm{~m}$. One up trap and one down trap was deployed on each pair of tree of heaven and on the second pair of host trees at each location. In total, 150 traps ( 75 up and 75 down) were installed on trees across the five sites (Table 1). Traps were deployed on the same trees in both years of study, which spanned the 2014 and 2015 growing seasons.

In 2014, the trees selected for trapping were prepared by clearing the vegetation from around their base and by removing any vines growing on them. The funneling portions of all traps were installed between 14 April and 14 May and installation of the collections jars was on 14 May. After the 2014 season, the collection jar from all traps and the plastic funnel from down traps were removed, while the mesh funnel of the up traps and the plastic strip of the down traps were left in the field. Since vegetation around the base of these trees was periodically removed during the 2014 season, no site 
preparation was necessary in 2015, when the collection jars were installed on 13 May. The mean $( \pm$ SE) height at which the up traps (i.e. collection jar) were installed on fruit and wild trees was $51.04 \pm 1.81 \mathrm{~cm}$ and $87.18 \pm 1.55 \mathrm{~cm}$, respectively. The mean ( \pm SE) height at which the down traps were installed on fruit and wild trees was $30.02 \pm 1.38 \mathrm{~cm}$ and $83.92 \pm 0.89 \mathrm{~cm}$, respectively. From 14 May-16 October, 2014, and 13 May-30 September, 2015, $H$. halys adults and nymphs captured in each trap were removed and counted weekly. Instars were identified using the characteristics described by Hoebeke and Carter (2003). Captures in traps that were destroyed by animals or compromised by unfavorable weather conditions (e.g., broken collection jar, torn mesh, detached plastic collar) were not recorded; however, this affected only $\sim 1 \%$ of all observations across years, and all damaged traps were repaired or replaced immediately.

\section{Data Analyses}

All statistical analyses were conducted using JMP Pro version 11 (SAS Institute Inc., Cary, NC, 2007) and outcomes were considered significant at $P<0.05$. Since annual total captures varied substantially, seasonal trends for nymph captures were compared between years using weekly percentages of total captures, and nonparametric Spearman's correlation was used to determine the relationship between the yearly trends. Percentages of the different instars captured weekly were computed for each year.

For parametric analyses, data that did not satisfy the assumptions of normality were transformed using arcsine-square root for percentage data and $\log (x+1)$ for count data. Comparisons of the mean weekly percentage of total captures between years and the difference between the overall upward and downward captures of nymphs were conducted using Student's $t$-test. A repeated measures ANOVA using date as the repeated variable was used to compare total weekly captures of upward- and downward-moving nymphs throughout the trapping period for each year. One-way ANOVA was used to compare mean weekly captures in up and down traps among the different tree species for each year and among three distinct periods during the field season (early, middle, and late), using only data from the period during which nymphs were captured. This approach was similar to that reported by Leskey et al. (2015) for pheromone trapping of $H$. halys. In the present study, the early season period began at the onset of nymph captures and the three periods spanned 12 June-1 October, 2014, and 13 June-30 September, 2015. In 2014, early, middle, and late-season captures were from 12 June-16 July, 17 July-27 August, and 28 August-1 October, respectively. In 2015, the early, middle, and late season periods corresponded to captures during 13 June-15 July, 16 July-26 August, and 27 August-30 September, respectively. Significant differences among treatment means were compared using Tukey's HSD.

Captures of nymphs were examined in relation to the seasonal phenology of $H$. halys, based on degree-day accumulations calculated using the sine-wave method (Baskerville and Emin 1969) and the $14.17^{\circ} \mathrm{C}$ lower developmental threshold established by Nielsen et al. (2008). Since ovarian development of overwintering female $H$. halys begins at a photoperiod of $\sim 14 \mathrm{~h}$ (reviewed in Lee et al. 2013 b), biofix for initiating degree-day accumulations was the date on which the photophase reached 14h (5 May 2014 and 6 May 2015). It was assumed that oviposition started on 15 May in both years, based on the preoviposition period reported by Nielsen and Hamilton (2009). Estimated onset of eclosion of first-generation adults was based on the reported degree-day requirement for $H$. halys development (egg to adult), which was between 538 DD
(Nielsen et al. 2008) and 570 DD (Leskey et al. 2012d). Here, we used both estimates to present a range of the period during which $F_{1}$ adults were estimated to be first present. Subsequently, based on the preoviposition period previously reported ( 147 DD; Nielsen et al. 2008), we estimated the period when F2 nymphs could be present following $\mathrm{F}_{1}$ adult eclosion, which was $\sim 742 \mathrm{DD}$ and $\sim 736 \mathrm{DD}$ in 2014 and 2015, respectively.

\section{Results}

\section{Tree Census}

Of the 47 species of trees from 19 families recorded from sampling at the border and in the interior of unmanaged woodlands adjacent to apple orchards, $36(76.6 \%)$ of these have been reported as hosts of $H$. halys (Table 2). The five most common species at the woods edge were tree of heaven, common hackberry, sassafras, spicebush, and black locust, while in the interior, common hackberry, green ash, spicebush, black cherry, and eastern redbud were the five most common species encountered. Pooling the data from the border and interior sampling areas, the five most abundant species included tree of heaven $(17 \%)$, common hackberry $(11 \%)$, sassafras $(7 \%)$, spicebush $(6 \%)$, and green ash $(6 \%)$.

\section{Nymph Trapping}

Based on pooled captures from both up and down traps across all sites and tree species, $90 \%$ and $84 \%$ of all $H$. halys captured were nymphs in 2014 and 2015, respectively, with the remainder being adults. In both 2014 and 2015, the first nymph was captured during the same week in mid-June. Total nymph captures were higher in $2014(n=729)$ than in $2015(n=278)$. Despite large difference in total nymph captures between years, the mean weekly percentage of total captures was not significantly different between 2014 and $2015(t=-0.19, \mathrm{df}=41, P=0.85)$ and the seasonal trends were remarkably similar and significantly positively correlated (Fig. 2; Spearman's correlation: $\left.r_{s}=0.09 ; P>0.0001\right)$. Weekly data pooled across all sites showed that significantly more upward- than downward-walking nymphs were captured in 2014 (77\% up and $23 \%$ down; $t=-2.75, \mathrm{df}=42, P=0.01)$ and 2015 (86\% up and $14 \%$ down; $t=-3.29, \mathrm{df}=38, P=0.0021)$. Data pooled across all sites also showed that nymph captures in both up and down traps differed significantly throughout the season in $2014\left(F_{21}\right.$, $2058=2.31, P=0.0006$; Fig. $3 \mathrm{~A})$ and $2015\left(F_{19}, 2299=3.34\right.$, $P<0.0001$; Fig. 3B).

Based on degree-day accumulations, the onset of $\mathrm{F}_{1}$ adult eclosion was estimated to have occurred between 22-26 July 2014 (Fig. 3A) and 18-21 July 2015 (Fig. 3B). Nymphs captured before those dates were assumed to be predominantly the $F_{1}$ progeny of overwintered adults. Nymphs captured during the peak between late July and early August were assumed to be a combination of $F_{1}$ and $F_{2}$ nymphs, while those captured from mid-August onward were assumed to be mostly the $\mathrm{F}_{2}$ progeny of summer generation adults.

In $2014,54.6 \%$ of the nymphs captured were second instars. First, third, fourth, and fifth instars comprised $0.20 \%, 20.1 \%$, $12.1 \%$, and $13 \%$ of captures, respectively. Similarly, $57.5 \%$ of the nymphs captured in 2015 were in the second instar. First, third, fourth, and fifth instars comprised $0.40 \%, 18.5 \%, 7.7 \%$, and $15.9 \%$ of captures, respectively. The temporal distribution of the instars captured was similarly variable throughout the season in 2014 (Fig. 4A) and 2015 (Fig. 4B). In both years, second and third instars predominated from mid-June through late August, while fourth and fifth instars were most abundant from early September onward. In 
Table 2. Tree species identified at the edge and interior of woodlands bordering 15 apple orchards in Virginia and West Virginia

\begin{tabular}{|c|c|c|c|c|c|c|c|}
\hline \multirow[t]{2}{*}{ Family } & \multirow[t]{2}{*}{ Scientific name } & \multirow[t]{2}{*}{ Common name } & \multicolumn{2}{|c|}{ Exterior } & \multicolumn{2}{|c|}{ Interior } & \multirow[t]{2}{*}{ H. halys host } \\
\hline & & & Count & $\%$ & Count & $\%$ & \\
\hline \multirow[t]{4}{*}{ Aceraceae } & Acer platanoides $\mathrm{L}$. & Norway maple & 14 & 0.92 & 21 & 2.49 & $\mathrm{Yes}^{a}$ \\
\hline & Acer negundo L. & Boxelder & 5 & 0.33 & 6 & 0.71 & Yes $^{a}$ \\
\hline & Acer rubrum $\mathrm{L}$. & Red maple & 9 & 0.59 & 1 & 0.12 & $\mathrm{Yes}^{a, b}$ \\
\hline & Acer spp. & Maple & 0 & 0.00 & 5 & 0.59 & $\mathrm{Yes}^{b, c}$ \\
\hline \multirow[t]{2}{*}{ Anacardiaceae } & Rhus glabra L. & Smooth sumac & 6 & 0.39 & 4 & 0.47 & $\mathrm{Yes}^{b}$ \\
\hline & Toxicodendron pubescens Mill. & Poison-oak & 3 & 0.20 & 0 & 0.00 & No \\
\hline \multirow[t]{3}{*}{ Betulaceae } & Betula lenta $\mathrm{L}$. & Sweet birch & 18 & 1.18 & 13 & 1.54 & No \\
\hline & Carpinus caroliniana Walter & Hornbeam & 1 & 0.07 & 5 & 0.59 & No \\
\hline & Ostrya virginiana (Mill.) K. Koch & Hop hornbeam & 12 & 0.79 & 4 & 0.47 & No \\
\hline \multirow{2}{*}{ Caprifoliaceae } & Viburnum prunifolium $\mathrm{L}$. & Blackhaw & 43 & 2.83 & 21 & 2.49 & $\mathrm{Yes}^{a}$ \\
\hline & Viburnum acerifolium $\mathrm{L}$. & Mapleleaf viburnum & 10 & 0.66 & 0 & 0.00 & No \\
\hline \multirow[t]{2}{*}{ Cornaceae } & Cornus florida $\mathrm{L}$. & Flowering dogwood & 11 & 0.72 & 23 & 2.73 & $\mathrm{Yes}^{a, b}$ \\
\hline & Nyssa sylvatica Marsh. & Blackgum & 8 & 0.53 & 14 & 1.66 & $\mathrm{Yes}^{a}$ \\
\hline Elaeagnaceae & Elaeagnus umbellate Thunb. & Autumn olive & 6 & 0.39 & 3 & 0.36 & $\mathrm{Yes}^{a, b}$ \\
\hline \multirow[t]{7}{*}{ Fabaceae } & Cercis canadensis $\mathrm{L}$. & Eastern redbud & 8 & 0.53 & 55 & 6.52 & $\mathrm{Yes}^{\mathrm{a}, b}$ \\
\hline & Gleditsia triacanthos $\mathrm{L}$. & Honeylocust & 6 & 0.39 & 8 & 0.95 & $\mathrm{Yes}^{a}$ \\
\hline & Robinia pseudoacacia L. & Black locust & 70 & 4.60 & 1 & 0.12 & Yes $^{a, b}$ \\
\hline & Quercus alba $\mathrm{L}$. & White oak & 24 & 1.58 & 26 & 3.08 & $\mathrm{Yes}^{a, b}$ \\
\hline & Quercus velutina Lam. & Black oak & 21 & 1.38 & 24 & 2.84 & No \\
\hline & Quercus montana Willd. & Chestnut oak & 15 & 0.99 & 13 & 1.54 & Yes $^{b}$ \\
\hline & Quercus rubra L. & Northern red oak & 8 & 0.53 & 4 & 0.47 & Yes $^{a}$ \\
\hline \multirow[t]{5}{*}{ Juglandaceae } & Carya tomentosa (L.) Nutt. & Mockernut hickory & 35 & 2.30 & 22 & 2.61 & $\mathrm{Yes}^{b, c}$ \\
\hline & Carya glabra (Mill.) Sweet & Pignut hickory & 34 & 2.23 & 22 & 2.61 & $\mathrm{Yes}^{b, c}$ \\
\hline & Carya cordiformis (Wangenh.) L. Koch & Bitternut hickory & 60 & 3.94 & 8 & 0.95 & Yes $^{b, c}$ \\
\hline & Carya ovata (Mill.) K. Koch & Shagbark hickory & 9 & 0.59 & 2 & 0.24 & Yes $^{a, b, c}$ \\
\hline & Juglans nigra $\mathrm{L}$. & Black walnut & 12 & 0.79 & 2 & 0.24 & $\mathrm{Yes}^{a, b}$ \\
\hline \multirow[t]{2}{*}{ Lauraceae } & Lindera benzoin (L.) Blume & Spicebush & 77 & 5.06 & 69 & 8.18 & No \\
\hline & Sassafras albidum (Nutt.) Nees & Sassafras & 128 & 8.41 & 34 & 4.03 & $\mathrm{Yes}^{a, b}$ \\
\hline \multirow[t]{2}{*}{ Magnoliaceae } & Liriodendron tulipifera $\mathrm{L}$. & Tulip poplar & 37 & 2.43 & 28 & 3.32 & $\mathrm{Yes}^{a, b}$ \\
\hline & Magnolia acuminate $\mathrm{L}$. & Cucumber tree & 0 & 0.00 & 3 & 0.36 & No \\
\hline \multirow[t]{2}{*}{ Moraceae } & Morus rubra $\mathrm{L}$. & Red mulberry & 18 & 1.18 & 11 & 1.30 & Yes $^{b, c}$ \\
\hline & Morus spp. & Mulberry & 0 & 0.00 & 5 & 0.59 & $\mathrm{Yes}^{b, c}$ \\
\hline \multirow[t]{2}{*}{ Oleaceae } & Fraxinus pennsylvanica Marsh. & Green ash & 54 & 3.55 & 79 & 9.36 & Yes $^{a, b, c}$ \\
\hline & Fraxinus americana $\mathrm{L}$. & White ash & 39 & 2.56 & 40 & 4.74 & Yes $^{a, b, c}$ \\
\hline \multirow[t]{3}{*}{ Pinaceae } & Pinus strobus L. & Eastern white pine & 0 & 0.00 & 9 & 1.07 & No \\
\hline & Tsuga canadensis $\mathrm{L}$. & Eastern hemlock & 0 & 0.00 & 1 & 0.12 & $\mathrm{Yes}^{a}$ \\
\hline & Pinus spp. & Pine & 1 & 0.07 & 0 & 0.00 & No \\
\hline Platanaceae & Platanus occidentalis L. & American sycamore & 4 & 0.26 & 1 & 0.12 & $\mathrm{Yes}^{a, b}$ \\
\hline \multirow[t]{3}{*}{ Rosaceae } & Prunus serotine Ehrh. & Black cherry & 60 & 3.94 & 63 & 7.46 & Yes $^{a, b}$ \\
\hline & Prunus avium $\mathrm{L}$. & Sweet cherry & 16 & 1.05 & 13 & 1.54 & $\mathrm{Yes}^{a}$ \\
\hline & Crataegus spp. & Hawthorn & 3 & 0.20 & 0 & 0.00 & $\mathrm{Yes}^{a, c}$ \\
\hline Scrophulariaceae & Paulownia tomentosa (Thunb.) Siebold \& Zucc. ex. Steud & Paulownia & 5 & 0.33 & 0 & 0.00 & Yes $^{a, b}$ \\
\hline Simaroubaceae & Ailanthus altissima (Mill.) Swingle & Tree of heaven & 374 & 24.57 & 32 & 3.79 & Yes $^{a, b}$ \\
\hline Tiliaceae & Tilia americana $\mathrm{L}$. & American basswood & 14 & 0.92 & 0 & 0.00 & Yes $^{a, b}$ \\
\hline \multirow[t]{3}{*}{ Ulmaceae } & Celtis occidentalis $\mathrm{L}$. & Common hackberry & 174 & 11.43 & 96 & 11.37 & No \\
\hline & Ulmus rubra Muhl. & Slippery elm & 55 & 3.61 & 48 & 5.69 & $\mathrm{Yes}^{a, b, c}$ \\
\hline & Ulmus americana $\mathrm{L}$. & American elm & 15 & 0.99 & 5 & 0.59 & Yes $^{a, b, c}$ \\
\hline
\end{tabular}

Species in bold font in each column are the five most abundant species in each sampled area.

${ }^{a}$ Stopbmsb.org.

${ }^{b}$ Bakken et al. (2015).

${ }^{c}$ Unspecified species.

both years, only fifth instars were captured at the end of the sampling period.

In 2014, based on pooled data across the period of sampling during which nymphs were captured, mean weekly captures of nymphs in up and down traps differed significantly among the seven tree species from which sample sizes enabled analysis (up: $F_{6}, 1097=7.45$, $P<0.0001$; down: $\left.F_{6,1109}=5.63, P<0.0001\right)$. Highest captures of upward-walking nymphs were recorded from tree of heaven and black cherry while lowest captures were from apple, peach, and hackberry. Mean captures of nymphs walking up black locust and sassafras were intermediate. Captures in down traps in 2014 were significantly highest on peach and did not vary among the rest of the tree hosts. Significant differences in captures of nymphs in up and down traps among the seven tree species were observed during the early season (up: $F_{6}, 336=4.0, P=0.0007$; down: $F_{6}, 341=2.63$, $P=0.02$; Fig. 5A) and mid-season (up: $F_{6}, 406=4.04, P=0.0006$; down: $F_{6}, 411=4.37, P=0.0003$; Fig. $5 \mathrm{~B}$ ), while captures in up and down traps among the seven tree species did not differ significantly 


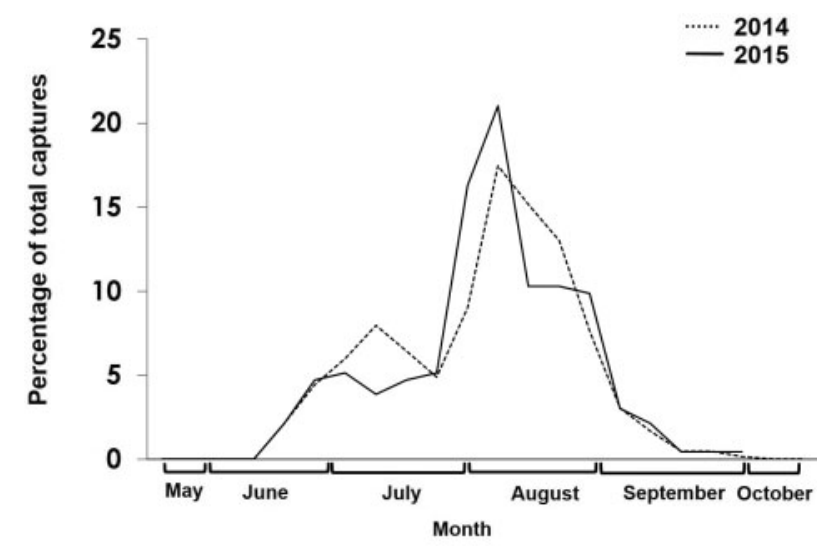

Fig. 2. Weekly percentage of total seasonal captures of H. halys nymphs, pooled across all sites and tree species, 2014 and 2015.

A

2014

\begin{tabular}{llllllllllll} 
Degree-days & 100 & 200 & 300 & 400 & 500 & 600 & 700 & 800 & 900 & 1000 & 1100 \\
\hline
\end{tabular}

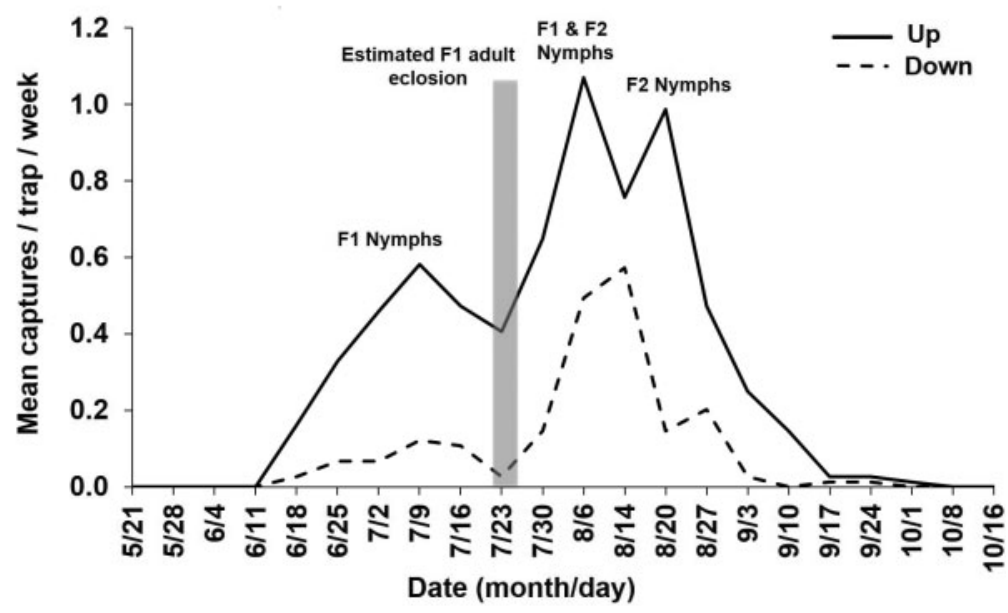

B 2015

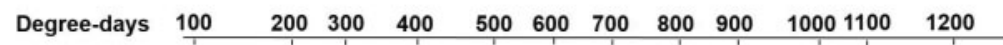

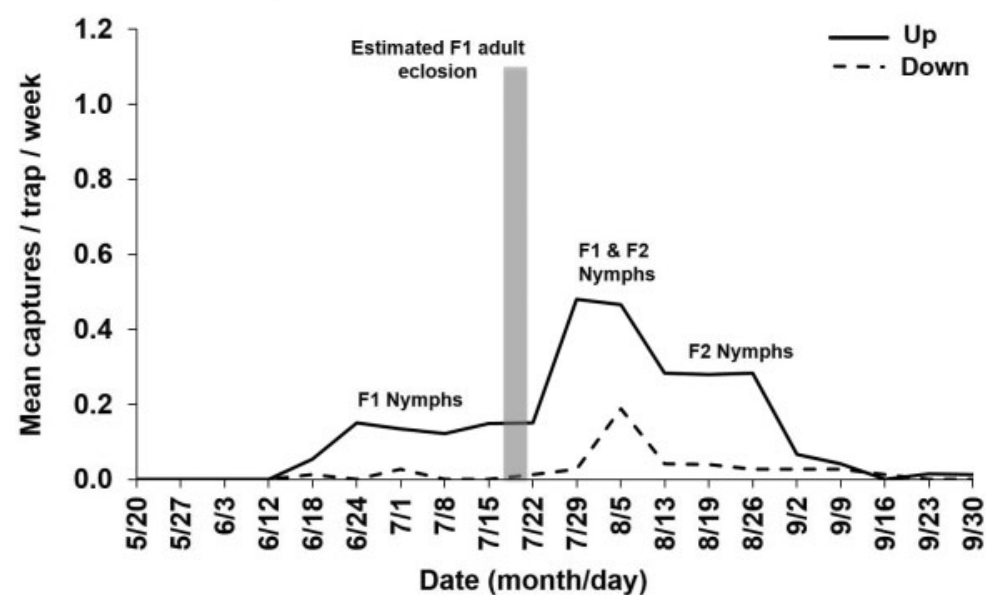

Fig. 3. Mean weekly captures of $H$. halys nymphs in up $(N=75)$ and down $(N=75)$ trunk traps on selected wild and fruit tree hosts at the orchard-woodland interface at apple and peach orchard sites in Virginia and West Virginia in 2014 (A) and 2015 (B). Degree-day accumulations and estimations of $H$. halys phenology are provided. Gray bar indicates the estimated period when $F_{1}$ adults were first present. 
A 2014

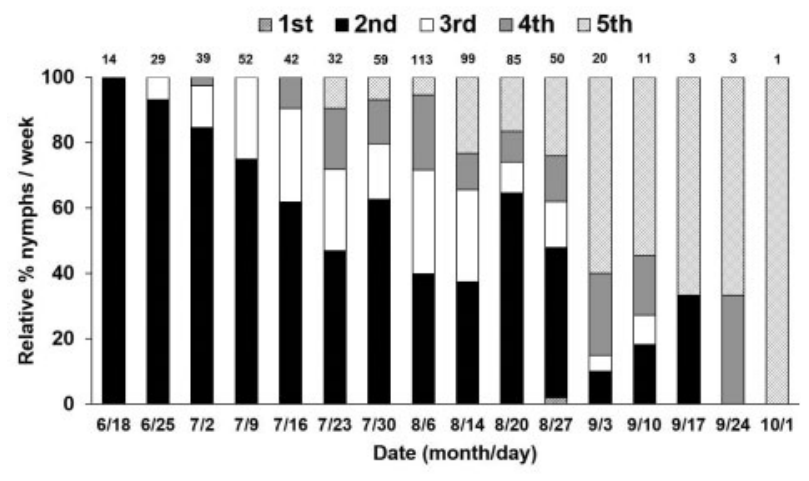

B

2015

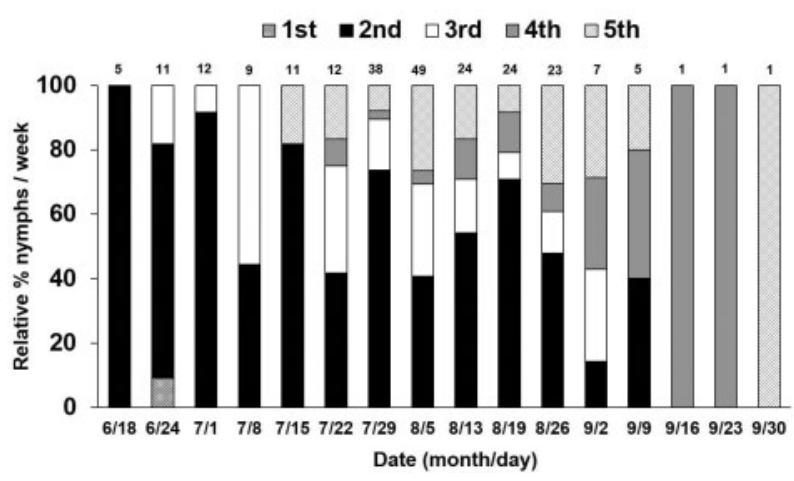

Fig. 4. Weekly distribution of $H$. halys instars captured in up $(N=75)$ and down $(N=75)$ traps on the trunk of selected wild and fruit tree hosts at the orchardwoodland interface at apple and peach orchard sites in Virginia and West Virginia from 18 June to 1 October, 2014 (A) and from 18 June to 30 September, 2015 (B) (no nymphs were captured prior to the week of 18 June). Numbers atop bars indicate total weekly captures.

during late season (up: $F_{6}, 341=1.33, P=0.24$; down: $F_{6}, 343=0.97$, $P=0.44$; Fig. 5C). Interestingly, about $60 \%$ of the nymphs captured in the down traps on peach trees in 2014 occurred after all the fruit were removed on 7 August. No such trend was observed on apples, likely due to low season-long captures in down traps on that host in both years.

In 2015 , based on data pooled across the periods when nymphs were found, captures in up traps differed significantly $\left(F_{6,1094}=4.22\right.$, $P=0.0003$ ) among the seven tree species from which sample sizes enabled analysis while captures in down traps did not differ among the tree hosts $\left(F_{6,1105}=0.61, P=0.72\right)$. Highest captures in up traps were observed on tree of heaven and were significantly higher than captures on apple and peach. Captures of nymphs in up traps on black cherry, black locust, hackberry, and sassafras were intermediate and statistically comparable to tree of heaven and the two cultivated hosts. Significant differences in captures in up traps among the seven tree species occurred during the early $\left(F_{6}, 336=2.6, P=0.018\right.$; Fig. 5D) and middle parts of the season $\left(F_{6,409}=3.12, P=0.005\right.$; Fig. 5E). There were no significant differences in captures among the seven tree species in up traps late in the season $\left(F_{6,409}=3.12\right.$, $P=0.005$; Fig. 5F) or in down traps during early, middle, and late season $\left(F_{6}, 341=1.65, P=0.1314 ; F_{6}, 409=0.81, P=0.56\right.$; $F_{6,341}=0.59, P=0.74$, respectively; Fig. $\left.5 \mathrm{D}-\mathrm{F}\right)$.

\section{Discussion}

Baseline information about the species and relative abundance of trees growing in unmanaged woodlands adjacent to apple orchards in
Virginia and West Virginia has provided additional context about the biotic factors that likely influence $H$. halys populations and pest pressure in orchards in this region, where its populations have been highest and most damaging since the initial outbreak in 2010. Most (76.6\%) of the 47 tree species recorded have been reported as reproductive and/ or feeding hosts for $H$. halys (Bakken et al. 2015, StopBMSB.org). Bakken et al. (2015) documented the presence of all life stages on the most common species reported here, tree of heaven, hackberry, sassafras, and green ash. Tree of heaven was the most common species at the woods edge and consistently among the hosts on which Bakken et al. (2015) found the highest $H$. halys populations. We note that since this survey only represented sites in two Mid-Atlantic states, it likely does not reflect the tree community in other regions where $H$. halys populations have established (see StopBMSB.org).

Data from passive trunk traps installed on fruit tree and wild tree hosts at the orchard-woodland interface confirmed that $H$. halys nymphs move onto and off of host trees throughout most of the growing season and revealed notable annual consistencies in their temporal and directional patterns of movement over two seasons. Relative to 2014, the $62 \%$ decrease in total captures in 2015 was undoubtedly associated and consistent with numerous reports of lower $H$. halys populations in 2015 (StopBMSB.org), following an unusually cold winter and likely high mortality of overwintering adults based on their reported cold tolerance (Cira et al. 2016). However, despite this difference in the $H$. halys population, the percentage of weekly captures was very similar between years and indicated consistent seasonal trends. It is noteworthy that first nymph captures and peak captures occurred during the same week each year. 


\section{4}

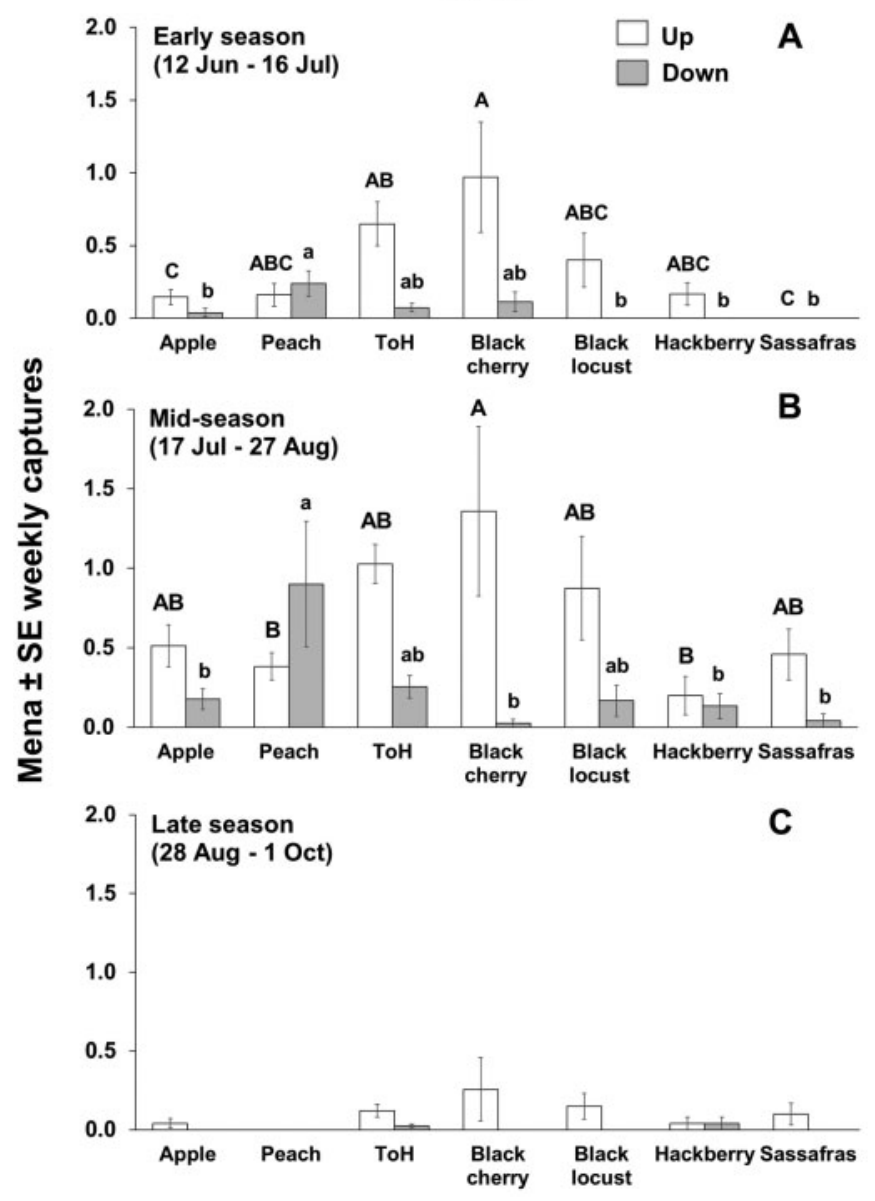

2015
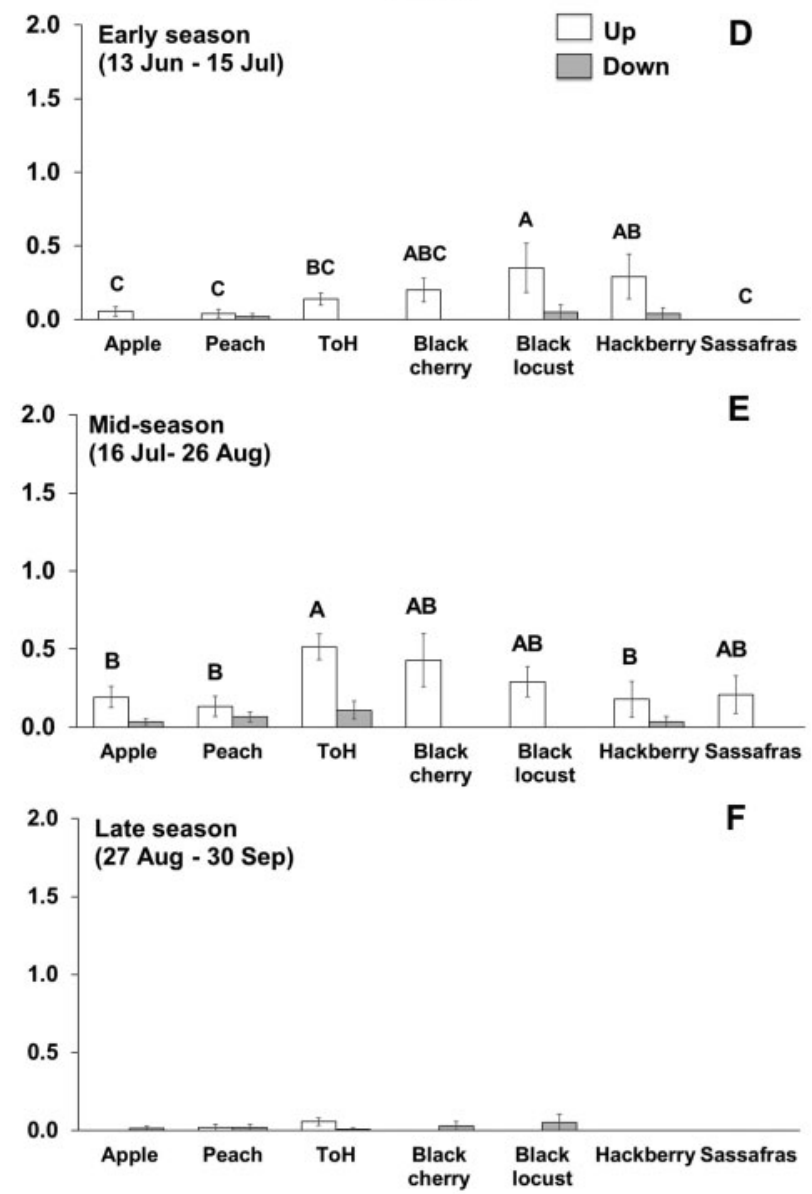

Fig. 5. Captures of $H$. halys nymphs in up $(N=75)$ and down $(N=75)$ traps on the trunk of selected wild and fruit tree hosts at the orchard-woodland interface at apple and peach orchard sites in Virginia and West Virginia from 18 June to 1 October, 2014 (A-C) and 18 June to 30 September, 2015 (D-F). Tree host ( $n$ ): apple (25), peach (25), tree of heaven (ToH) (25), black cherry (7), black locust (4), hackberry (5), and sassafras (4). Tree hosts with $n=1$ (black walnut, boxelder, mulberry, sweet cherry, and green ash) were excluded from the analyses. Bars with the same letters are not significantly different at $\alpha=0.05$. Upper and lowercase letters above bars correspond to comparisons for up and down traps, respectively.

Nymphs actively moved off of and onto host trees via the main trunk. However, most captures were in up traps in both years, conforming to results from Acebes-Doria et al. (2016c), who found that $88 \%$ of the nymphs captured were in up traps and to those from Moeed and Meads (1983), who reported that $80 \%$ of 22,696 invertebrates trapped on trees in a New Zealand forest were in up traps. Acebes-Doria et al. (2016c) also showed that second-instar H. halys nymphs were positively phototactic and negatively geotactic, which may partially explain the consistently higher captures in up traps. In addition, Moeed and Meads (1983) suggested that arthropod dispersal from host trees may be mainly via dropping rather than walking. Numerous anecdotal observations have indicated that $H$. halys adults and nymphs drop from host plants when disturbed (Dively et al. 2015), suggesting that this behavior also may be associated with the dispersal of nymphs from host trees and possibly further explain higher captures in up traps. In 2014, we attempted to examine whether nymphs disperse from trees via dropping by placing sets of upward-facing, 36.83- $\mathrm{cm}^{2}$ traps coated with Tanglefoot (The Tanglefoot Company, Grand Rapids, Michigan) on stands beneath of canopy of female tree of heaven trees for 7-d intervals over $3 \mathrm{wk}$, but were unable to document this behavior, possibly due to the small trapping surface area and to the ability of nymphs (especially older nymphs) to extricate themselves from the sticky material (demonstrated in subsequent laboratory studies).

Similar to the results reported by Acebes-Doria et al. (2016c), more second instars than other instars were captured and there are three plausible reasons for this, which are not necessarily mutually exclusive. First, H. halys life table analyses by Haye et al. (2014) showed higher survivorship of second instars than later instars, suggesting that the former are more abundant in the field. Second, after acquiring gut microsymbionts by feeding on the egg mass during the first instar (Taylor et al. 2014), second instars disperse and begin feeding on host plant tissues; hence increased dispersal activity and captures of this instar may be expected. Third, Acebes-Doria et al. (2016b) showed that with the exception of peach, which supported the completion of nymphal development as a single host, the survivorship and development of $H$. halys nymphs was significantly improved when they were given access to plant tissue from more than one host. Consequently, it may be that second instars that feed on the host on which eggs are laid and then disperse to and feed on another host will result in later instars that do not need to disperse to the same degree.

Studies in West Virginia and Virginia have indicated that $H$. halys is bivoltine in this region (Bakken et al. 2015, Leskey et al. 
2012d). Adult $H$. halys emergence from overwintering shelters begins in April and peaks between mid-May and early June (Bergh et al. 2016). Upon emergence, adults presumably feed on host plants before they reproduce. Oviposition begins between late May and mid-June (Nielsen and Hamilton 2009, Bakken et al. 2015) and, as mentioned previously, plant feeding by nymphs begins in the second instar. $F_{1}$ and $F_{2}$ adults are present, respectively, by mid-July and mid- to late July (Leskey et al. 2012d). Based on degree-day accumulations and the lower developmental threshold for $H$. halys (Nielsen et al. 2008), seasonal trends in nymph captures and temporal changes in the distribution of instars captured conformed to results from phenological studies by Leskey et al. (2012d). Capture trends in conjunction with the degree-day data also suggested that the $F_{1}$ and $F_{2}$ nymphal generations overlapped in mid-season (i.e., late July to early August), when highest captures were recorded. This agrees with Nielsen et al. (2016), who used a phenological model and field observations to show a high degree of overlap among life stages of $H$. halys (early and later instar nymphs and adults) and between generations, particularly during the period in the season with largest $H$. halys populations.

Seasonal changes in the distribution of the instars captured may have important management implications for the potential risk of injury to tree fruit. Acebes-Doria et al. (2016a) showed that injury to apples and peaches from feeding by nymphs varied significantly according to the stage of nymphal development and to the point in the season at which feeding occurred. Late-season feeding on apple and peach by older nymphs resulted in more economic injury at harvest than feeding by young nymphs early in the season, and feeding by older nymphs caused injury equivalent to that from adults. To date, provisional pheromone trap-based thresholds for $H$. halys management in apple orchards have relied solely on adult captures (Short et al. 2016), although nymphs are also present in the field and captured in traps in and near orchards (Weber et al. 2014, Leskey et al. 2015). Additionally, Joseph et al. (2015) found that injury from $H$. halys to apples was highest during mid- and lateseason. Collectively, these findings indicate nymphs likely contribute to damage found in commercial orchard systems, though their impact relative to adults is unknown and their inclusion in thresholdbased management protocols has not been explored.

This study was not designed or intended to evaluate seasonal patterns of host use by $H$. halys nymphs. Consequently, we cannot draw unequivocal conclusions about this highly complex question, which is likely influenced by, 1) host selection by ovipositing females, 2) the relative suitability of individual tree species for nymphal development and seasonal changes in their suitability, 3) potentially different nutritional requirements and dispersal propensity of early versus later instars, and 4) continuously varying tree species composition along the edge of woodlands adjacent to fruit orchards. However, our study revealed notable differences in the upward and downward movement of nymphs among different host trees. Interestingly, it was consistent in both years that upward and downward movement of nymphs were equivalent among the seven tree species later in the season while significant differences were found for their upward movement among the tree species during early and middle parts of the season. This may be attributed to the greater abundance of nymphs during the early and the middle parts of the season than in late season. Notably, in both years, total captures of nymphs walking up trunks of wild hosts such as tree of heaven, black cherry, and black locust were higher than on peach and apple while the captures in down traps were highest on peach. There were also periods during which their upward or downward movement was noticeably higher on certain hosts. For example, upward captures on tree of heaven were particularly high during the first week of August, when tree of heaven samaras were mature. Moreover, highest captures on peach in 2014 were recorded from down traps after fruit were removed from the trees, paralleling the results of Martinson et al. (2015) who showed that H. halys nymphal and adult abundance decreased significantly when fruit from ornamental trees was removed completely. Martinson et al. (2015) also surveyed different ornamental trees known to be hosts of $H$. halys and found highest populations associated with trees bearing mature fruit. In combination with the results of Martinson et al. (2015), the considerable dispersal capacity of nymphs (Lee et al. 2014), their enhanced survivorship by feeding on more than one host (Acebes-Doria et al. 2016b), and the apparent variation in upward and downward movement on different hosts demonstrated here suggest that nymphs may have an underlying "need" to utilize different hosts during the season. Hence, the orchard-woodland interface may serve as an ideal environment for $H$. halys, given an assured food source (i.e., tree fruit) and the substantial diversity of wild hosts growing at the edge of the nearby woodlands. Not surprisingly, $H$. halys injury to apples was higher on trees in border rows next to woods than on those in the orchard interior blocks (Leskey et al. 2012c, Joseph et al. 2014). Indeed, our results further reinforce the need to develop perimeter-based, integrated management strategies such as "IPM-Crop Perimeter Restructuring" (Blaauw et al. 2015) and "attract- and-kill" for H. halys at orchard borders (Morrison et al. 2015) to manage this perimeter-driven threat. However, the relative contribution of specific wild hosts at the orchard-woodland interface to pest pressure from both $H$. halys adults and nymphs to orchard crops throughout the season remains a key question that warrants further study as risk assessments and these management strategies are developed and refined.

\section{Acknowledgments}

Our sincere appreciation to Torri Hancock for monitoring the traps at the USDA and Eliezer Doria who assisted greatly with the assembly, installation, and regular checking of traps. Thanks also to Zachary Moore and Jean Engelman for excellent technical assistance. This research was supported by USDA NIFA award 2011-51181-30937 and an award from the Pesticide Services Division of the Virginia Department of Agriculture and Consumer Services.

\section{Supplementary Data}

Supplementary data are available at Environmental Entomology online.

\section{References Cited}

Acebes-Doria, A. L., T. C. Leskey, and J. C. Bergh. 2016a. Injury to apples and peaches at harvest from feeding by Halyomorpha halys (Stål) (Hemiptera: Pentatomidae) nymphs early and late in the season. Crop Prot. 89: 58-65.

Acebes-Doria, A. L., T. C. Leskey, and J. C. Bergh. 2016b. Host plant effects on Halyomorpha halys (Hemiptera: Pentatomidae) nymphal development and survivorship. Environ. Entomol. 45: 663-670.

Acebes-Doria, A. L., T. C. Leskey, and J. C. Bergh. 2016c. Development and comparison of trunk traps to monitor movement of Halyomorpha halys nymphs on host trees. Entomol. Exp. Appl. 158: 44-53.

Bakken, A. J., S. C. Schoof, M. Bickerton, K. L. Kamminga, J. C. Jenrette, S. Malone, M. A. Abney, D. A. Herbert, Jr, D. Reisig, T. P. Kuhar, et al. 2015. Occurrence of brown marmorated stink bug (Hemiptera: Pentatomidae) on wild hosts in nonmanaged woodlands and soybean fields in North Carolina and Virginia. Environ. Entomol. 44: 1011-1021. 
Baskerville, G., and P. Emin. 1969. Rapid estimation of heat accumulation from maximum and minimum temperatures. Ecology 50: 514-517.

Bergh, J. C., W. R. Morrison, III, S. V. Joseph, and T. C. Leskey. 2016. Characterizing spring emergence of adult Halyomorpha halys (Hemiptera: Pentatomidae) using experimental overwintering shelters and commercial pheromone traps. Entomol. Exp. Appl. 9: e91575.

Blaauw, B. R., V. P. Jones, and A. L. Nielsen. 2016. Utilizing immunomarking techniques to track Halyomorpha halys (Hemiptera: Pentatomidae) movement and distribution within a peach orchard. PeerJ 4: e1997.

Blaauw, B. R., D. Polk, and A. L. Nielsen. 2015. IPM-CPR for peaches: incorporating behaviorally-based methods to manage Halyomorpha halys and key pests in peach. Pest. Manag. Sci. 71: 1513-1522.

Dively, G. P., C.R.R. Hooks, T. Patton, P. D. Venugopal, B. Aigner, J. Hogue, D. A. Herbert, Jr, T. Kuhar, S. Malone, E. Seymore, et al. 2015. Brown marmorated stink bug biology and management in Mid-Atlantic soybeans. (http://unitedsoybean.org/wp-content/uploads/54407_FINAL_MidAtlantic_StinkBug_book.pdf).

Cira, T. M., R. C. Venette, J. Aigner, T. Kuhar, D. E. Mullins, S. E. Gabbert, and W. D. Hutchison. 2016. Cold tolerance of Halyomorpha halys (Hemiptera: Pentatomidae) across geographic and temporal scales. Environ. Entomol. 45: 484-491.

Funayama, K. 2006. A new rearing method using carrots as food for the brown-marmorated stink bug, Halyomorpha halys (Stål) (Heteroptera: Pentatomidae). Appl. Entomol. Zool. 41: 415-418.

Haye, T., S. Abdallah, T. Gariepy, and D. Wyniger. 2014. Phenology, life table analysis and temperature requirements of the invasive brown marmorated stink bug, Halyomorpha halys, in Europe. J. Pest Sci. 87: 407-418.

Hoebeke, E. R., and M. E. Carter. 2003. Halyomorpha halys (Stål) (Heteroptera: Pentatomidae): a polyphagous plant pest from Asia newly detected in North America. Proc. Entomol. Soc. Wash. 105: 225-237.

Joseph, S., C. Bergh, S. Wright, and T. Leskey. 2013. Factors affecting captures of brown marmorated stink bug, Halyomorpha halys (Hemiptera: Pentatomidae), in baited pyramid traps. J. Entomol. Sci. 48: 43-51.

Joseph, S. V., J. W. Stallings, T. C. Leskey, G. Krawczyk, D. Polk, B. Butler, and J. C. Bergh. 2014. Spatial distribution of brown marmorated stink bug (Hemiptera: Pentatomidae) injury at harvest in mid-Atlantic apple orchards. J. Econ. Entomol. 107: 1839-1848.

Joseph, S. V., M. Nita, T. C. Leskey, and J. C. Bergh. 2015. Temporal effects on the incidence and severity of brown marmorated stink bug (Hemiptera: Pentatomidae) feeding injury to peaches and apples during the fruiting period in Virginia. J. Econ. Entomol. 108: 592-599.

Kuhar, T., H. Doughty, K. Kamminga, and L. Lilliston. 2012. Evaluation of insecticidesusing bean dip bioassay for control of brown marmorated stink bug, 2011. Arthropod Manag. Tests 37: L1. [WorldCat]

Lee, D. H., S. E. Wright, and T. C. Leskey. 2013a. Impact of insecticide residue exposure on the invasive pest, Halyomorpha halys (Hemiptera: Pentatomidae): analysis of adult mobility. J. Econ. Entomol. 106: 150-158.

Lee, D. H., B. D. Short, S. V. Joseph, J. C. Bergh, and T. C. Leskey. 2013b. Review of the biology, ecology, and management of Halyomorpha halys (Hemiptera: Pentatomidae) in China, Japan, and the Republic of Korea. Environ. Entomol. 42: 627-641.

Lee, D. H., A. L. Nielsen, and T. C. Leskey. 2014. Dispersal capacity and behavior of nymphal stages of Halyomorpha halys (Hemiptera: Pentatomidae) evaluated under laboratory and field conditions. J. Insect Behav. 27: 639-651.

Lee, D. H., and T. C. Leskey. 2015. Flight behavior of foraging and overwintering brown marmorated stink bug, Halyomorpha halys (Hemiptera: Pentatomidae). Bull. Entomol. Res. 105: 566-573.

Leskey, T. C., G. C. Hamilton, A. L. Nielsen, D. F. Polk, C. Rodriguez-Saona, J. C. Bergh, D. A. Herbert, T. P. Kuhar, D. Pfeiffer, G. P. Dively, et al. 2012a. Pest status of the brown marmorated stink bug, Halyomorpha halys in the USA. Outlooks Pest Manag. 23: 218-226.

Leskey, T. C., D. H. Lee, B. D. Short, and S. E. Wright. 2012b. Impact of insecticides on the invasive Halyomorpha halys (Hemiptera: Pentatomidae): analysis of insecticide lethality. J. Econ. Entomol. 105: 1726-1735.

Leskey, T. C., B. D. Short, B. R. Butler, and S. E. Wright. 2012c. Impact of the invasive brown marmorated stink bug, Halyomorpha halys (Stål), in midAtlantic tree fruit orchards in the United States: case studies of commercial management. Psyche J. Entomol. 2012: 535062. DOI: 10.1155/2012/ 535062.

Leskey, T. C., S. E. Wright, B. D. Short, and A. Khrimian. 2012d. Development of behaviorally based monitoring tools for the brown marmorated stink bug, Halyomorpha halys (Stål) (Heteroptera: Pentatomidae) in commercial tree fruit orchards. J. Entomol. Sci. 47: 76-85.

Leskey, T. C., A. Agnello, J. C. Bergh, G. P. Dively, G. C. Hamilton, P. Jentsch, A. Khrimian, G. Krawczyk, T. P. Kuhar et al. 2015. Attraction of the invasive Halyomorpha halys (Hemiptera: Pentatomidae) to traps baited with semiochemical stimuli across the United States. Environ. Entomol. 44: 746-756.

Martinson, H. M., P. D. Venugopal, E. J. Bergmann, P. M. Shrewsbury, and M. J. Raupp. 2015. Fruit availability influences the seasonal abundance of invasive stink bugs in ornamental tree nurseries. J. Pest Sci. 88: 461-468.

Moeed, A., and M. Meads. 1983. Invertebrate fauna of four tree species in Orongorongo Valley, New Zealand, as revealed by trunk traps. N. Zeal. J. Ecol. 6: 39-53.

Morrison, W. R. I., D. H. Lee, B. D. Short, A. Khrimian, and T. C. Leskey. 2015. Establishing the behavioral basis for an attract-and-kill strategy to manage the invasive Halyomorpha halys in apple orchards. J. Pest Sci. 89: $81-96$.

Mulder, P., B. D. McCraw, W. Reid, and R. Grantham. 1999. Monitoring adult weevil populations in pecan and fruit trees in Oklahoma. Division of Agricultural Sciences and Natural Resources, Oklahoma State University.

Nielsen, A. L., G. C. Hamilton, and D. Matadha. 2008. Developmental rate estimation and life table analysis for Halyomorpha halys (Hemiptera: Pentatomidae). Environ. Entomol. 37: 348-355.

Nielsen, A. L., and G. C. Hamilton. 2009. Life history of the invasive species Halyomorpha halys (Hemiptera: Pentatomidae) in Northeastern United States. Ann. Entomol. Soc. Am. 102: 608-616.

Nielsen, A. L., S. Fleischer, and S. Chen. 2016. Coupling developmental physiology, photoperiod, and temperature to model phenology and dynamics of an invasive Heteropteran, Halyomorpha halys. Front. Physiol. 7: 165.

Rice, K. B., J. C. Bergh, E. J. Bergmann, D. J. Biddinger, C. Dieckhoff, G. Dively, H. Fraser, T. Gariepy, G. Hamilton, T. Haye, et al. 2014. Biology, ecology, and management of brown marmorated stink bug (Hemiptera: Pentatomidae). J. Integr. Pest Manag. 5: A1-A13.

Short, B. D., A. Khrimian, and T. C. Leskey. 2016. Development of pheromone-based decision support tools for management of Halyomorpha halys in apple orchards: development of a trap-based treatment threshold. J. Pest Sci. DOI:10.1007/s10340-016-0812-1, in press.

Taylor, C. M., P. L. Coffey, B. D. DeLay, and G. P. Dively. 2014. The importance of gut symbionts in the development of the brown marmorated stink bug, Halyomorpha halys (Stål). PLoS ONE 9: e90312.

Weber, D. C., T. C. Leskey, G. C. Walsh, and A. Khrimian. 2014. Synergy of aggregation pheromone with methyl (E, E, Z)-2, 4, 6-decatrienoate in attraction of Halyomorpha halys (Hemiptera: Pentatomidae). J. Econ. Entomol. 107: 1061-1068.

Wiman, N. G., V. M. Walton, P. W. Shearer, S. I. Rondon, and J. C. Lee. 2014. Factors affecting flight capacity of brown marmorated stink bug, Halyomorpha halys (Hemiptera: Pentatomidae). J. Pest Sci. 88: 37-47. 